\title{
Efficient Anaerobic Digestion of Microalgae Biomass: Proteins as a Key Macromolecule
}

\author{
Jose Antonio Magdalena ${ }^{1}$, Mercedes Ballesteros ${ }^{1,2}$ and Cristina González-Fernandez ${ }^{1, *}$ \\ 1 Biotechnological Processes Unit, IMDEA Energy, 28040 Madrid, Spain; \\ joseantonio.magdalena@imdea.org (J.A.M.); mercedes.ballesteros@imdea.org (M.B.) \\ 2 Biofuels Unit, CIEMAT, 28040 Madrid, Spain \\ * Correspondence: cristina.gonzalez@imdea.org \\ Academic Editor: Ivet Ferrer
}

Received: 12 March 2018; Accepted: 3 May 2018; Published: 6 May 2018

\begin{abstract}
Biogas generation is the least complex technology to transform microalgae biomass into bioenergy. Since hydrolysis has been pointed out as the rate limiting stage of anaerobic digestion, the main challenge for an efficient biogas production is the optimization of cell wall disruption/hydrolysis. Among all tested pretreatments, enzymatic treatments were demonstrated not only very effective in disruption/hydrolysis but they also revealed the impact of microalgae macromolecular composition in the anaerobic process. Although carbohydrates have been traditionally recognized as the polymers responsible for the low microalgae digestibility, protease addition resulted in the highest organic matter solubilization and the highest methane production. However, protein solubilization during the pretreatment can result in anaerobic digestion inhibition due to the release of large amounts of ammonium nitrogen. The possible solutions to overcome these negative effects include the reduction of protein biomass levels by culturing the microalgae in low nitrogen media and the use of ammonia tolerant anaerobic inocula. Overall, this review is intended to evidence the relevance of microalgae proteins in different stages of anaerobic digestion, namely hydrolysis and methanogenesis.
\end{abstract}

Keywords: microalgae; anaerobic digestion; proteins; biogas; inhibition

\section{Introduction}

Environmental issues and energy self-sufficiency concerns related to fossil fuels have led to research on new approaches to improve renewable energy production to substitute them. Anaerobic digestion is one of those technologies devoted to the production of biofuels, which involves the degradation of organic matter through the action of different microorganisms. Anaerobic digestion exhibits many advantages such as its efficiency for organic matter removal, its applicability at any scale and the wide variety of substrates that can be used as feedstock. Likewise, the multiproduct generation attained during digestion is also a major benefit of this technology. Those end-products, including biogas and digestate, are easy to separate and can be a source of energy and fertilizers, respectively [1].

Among the different substrates that can be employed, microalgae are being recently studied since this biomass can be grown in residual effluents, do not need arable land to be cultivated while contributing to $\mathrm{CO}_{2}$ mitigation and wastewater bioremediation [2]. Previous studies have demonstrated the technoeconomic and environmental benefits of microalgae biomass for bioenergy purposes when considered as by-product in other technologies [3-8]. In the same manner, out of the bioenergy producing technologies where microalgae can be used as feedstocks, anaerobic digestion is probably the most economically feasible since it does not require highly concentrated biomass [9] and anaerobes can use proteins, carbohydrates and lipids for methane production purposes [10]. Microalgae biomass has 
a wide range of compositions, depending on growth conditions and species [11,12]. In general terms, biochemical profile of chlorophytes range $30-60 \%$ of proteins, $20-40 \%$ of carbohydrates, and $4-57 \%$ of lipids [13,14]. Each macromolecule has different achievable methane yields [10]. Thus, in principle, different microalgae compositions produce different methane yields [12]. At the same time, microalgae composition varies depending not only among strains but also on the growth conditions (nutrients availability and operational conditions) $[15,16]$. In addition to the different macromolecular composition that microalgae might exhibit, this biomass also differs in structural features. Most of the microalgae able to thrive in wastewater effluents have a chemically complex and structurally robust cell wall composed of low biodegradable substances that hinder the anaerobic digestion [17,18]. Some of these compounds are sporopollenin, algaenan, and polymeric carbohydrates that offer a barrier towards anaerobes [19,20]. During anaerobic digestion, cell walls are degraded by extracellular enzymes of hydrolytic bacteria. Nevertheless, this process might be too slow and thus, a limited hydrolysis rate renders the anaerobic digestion as a lengthy and inefficient bioprocess. Pretreatments are used in order to facilitate the accessibility of these extracellular enzymes whereby improving hydrolysis stage. Different microalgae pretreatments have been studied such as thermal, chemical, mechanical or biological. Methane yields improvements achieved with those different pretreatments can be found elsewhere [21-24]. Out of the different pretreatments, biological approach is the most environmentally friendly [25]. Opposite to other pretreatments, the additional benefits of biological pretreatments are the absence of inhibiting by-products [26] and the high selectivity of the reactions [27]. This approach might not only be used for biomass hydrolysis but also to provide crucial information related to the macromolecule that reduces the anaerobic biodegradability of microalgae biomass. In this manner, this review summarizes the main results attained during the last years of research devoted to microalgae pretreatments in the biogas production context. Moreover, this period of research highlighted the importance of proteins on different stages of the digestion. This review attempts to provide comprehensive evidences of the key role of microalgae proteins.

\section{Pretreatment of Microalgae Biomass to Improve Biogas Production}

Since low biodegradability is a common issue in anaerobic digestion of different substrates (such as activated sludge, lignocellulose and photosynthetic microorganisms), a wide range of pretreatments are available to enhance the hydrolysis step [28]. Cell wall rupture or hydrolysis is needed to make available microalgae organic matter to anaerobic microorganisms [29]. Pretreatments are classified in four main groups, namely thermal, mechanical (ultrasound and microwave), chemical (acidic, alkaline, solvents and ozonation) and thermo-chemical (acid or alkali reagents addition combined with high temperatures) and biological (enzymes and microorganisms). Those pretreatments have been intensively studied during the last decade to improve biogas production of microalgae biomass (Table 1). Most of them have been assessed in Biochemical Methane Potential (BMP) assays (batch digestion mode). 
Table 1. Studied pretreatments to improve biogas production using microalgae as substrates.

\begin{tabular}{|c|c|c|c|c|c|}
\hline $\begin{array}{l}\text { High Demanding Energy } \\
\text { Pretreatments }\end{array}$ & Operation Mode & Biomass & Conditions & Methane Yield Increase & References \\
\hline \multirow{6}{*}{ Thermal } & Batch & Scenedesmus sp. & $\begin{array}{l}75^{\circ} \mathrm{C} \text { for } 10 \mathrm{~h} \\
95^{\circ} \mathrm{C} \text { for } 10 \mathrm{~h}\end{array}$ & $\begin{array}{l}58 \% \\
69 \%\end{array}$ & [29-31] \\
\hline & Batch & Scenedesmus sp. & $80^{\circ} \mathrm{C}$ for $15 \mathrm{~min}$ & $60 \%$ & [32] \\
\hline & Batch & Chlorella sp. & $\begin{array}{l}70^{\circ} \mathrm{C} \text { for } 30 \mathrm{~min} \\
90^{\circ} \mathrm{C} \text { for } 30 \mathrm{~min}\end{array}$ & $37 \% 48 \%$ & [33] \\
\hline & Batch & $\begin{array}{c}\text { Stigeoclonium sp. Monoraphidium sp } \\
\text { and Nitzschia }\end{array}$ & $130^{\circ} \mathrm{C}$ for $15-30 \mathrm{~min}$ & $28 \%$ & [31] \\
\hline & Semi-continuous & Chlorella sp. & $120^{\circ} \mathrm{C} 40 \mathrm{~min}$ & 1.5 -fold & [34] \\
\hline & Batch & Scenedesmus sp. & $128.9 \mathrm{KJ} / \mathrm{g}$ TS for $30 \mathrm{~min}$ & $87 \%$ & [32] \\
\hline \multirow[t]{2}{*}{ Mechanical } & Batch & $\begin{array}{l}\text { Monoraphidium sp. and } \\
\text { Stigeoclonium sp. }\end{array}$ & $26.7 \mathrm{KJ} / \mathrm{g}$ TS for $30 \mathrm{~min}$ & $85 \%$ & [31] \\
\hline & Batch & Mixture of microalgae biomass & 10; 27; 40; 57 KJ/g TS & $6-24 \%$ & [35] \\
\hline \multirow[t]{2}{*}{ Chemical } & Batch & Chlorella sp. and Scenedesmus sp. & $\begin{array}{c}\mathrm{CaO}(4 \text { and } 10 \% \mathrm{w} / \mathrm{w}) \text { at } \\
25,55 \text { and } 72{ }^{\circ} \mathrm{C}\end{array}$ & $25 \%$ & [36] \\
\hline & Batch & Chlorella sp. & $\begin{array}{c}4 \mathrm{M} \mathrm{H}_{2} \mathrm{SO}_{4} \text { at } 120^{\circ} \mathrm{C} \text { for } \\
20-40 \mathrm{~min}\end{array}$ & $72.5 \%$ & [37] \\
\hline $\begin{array}{l}\text { Low Demanding Energy } \\
\text { Pretreatments }\end{array}$ & & Biomass & Solubilization & Methane Yield & References \\
\hline \multirow{4}{*}{ Proteases } & Batch & $\begin{array}{l}\text { C. reinhardtii } \\
\text { C. vulgaris }\end{array}$ & $86-96 \%$ for both biomasses & $\begin{array}{c}51 \% \text { in Chlorella biomass } \\
7 \% \text { C. reindhartii }\end{array}$ & [38] \\
\hline & Batch & Scenedesmus sp. & $30 \%$ & 1.53-fold & [39] \\
\hline & Semi-continuous & C.vulgaris & $47 \%$ & $\begin{array}{l}\text { 2.6-fold } \\
5 \text { and 6.3-fold (OLR }=1.5 \mathrm{~g} / \mathrm{L} \mathrm{d}\end{array}$ & [39] \\
\hline & Semi-continuous & C. vulgaris & $54 \%$ & $\begin{array}{c}5 \text { and } .3 \text {-fold }(\mathrm{OLR}=1.5 \mathrm{~g} / \mathrm{Ld} \\
\text { and } \mathrm{OLR}=3 \mathrm{~g} / \mathrm{Ld})\end{array}$ & {$[40]$} \\
\hline Carbohydrases & Batch & C. vulgaris and Scenedesmus sp. & $84 \% 36 \%$ & 1.2 -fold & [41] \\
\hline
\end{tabular}




\subsection{High Energy Demanding Pretreatments}

Thermal, thermo-chemical and mechanical pretreatments are considered as high energy demanding processes and, in order to evaluate its efficiency, the final energy balance of the pretreatment process has to be addressed. Given that thermal energy is available in biogas production facilities, the most used pretreatment is thermal application. Thermal pretreatments involve biomass heat up in a wide range of temperatures $\left(50-270{ }^{\circ} \mathrm{C}\right.$ ) and reaction time (from minutes to hours). With regard to thermal application, the effect on the biomass depends on the microalgae strain and applied temperature [30]. Passos et al. [31] and Passos and Ferrer [42] applied thermal pretreatment to Scenedesmus sp. biomass at $75{ }^{\circ} \mathrm{C}$ and $95{ }^{\circ} \mathrm{C}$ for $10 \mathrm{~h}$ resulting in methane yield enhancement of $58 \%$ and $69 \%$, respectively . Similar values were attained by González-Fernández et al. [43] when treating Scenedesmus at $80^{\circ} \mathrm{C}$ for only $15 \mathrm{~min}$, highlighting the impact of temperature rather than the heating time as the most relevant parameter in thermal pretreatment. Similar temperatures were tested in Chlorella biomass $\left(70\right.$ and $\left.90^{\circ} \mathrm{C}\right)$ for $30 \mathrm{~min}$ resulting in an enhanced methane yield of $37 \%$ and $48 \%$ compared to the raw biomass (322 $\mathrm{mL} \mathrm{CH}_{4} / \mathrm{g} \mathrm{VS}_{\mathrm{in}}$ ) [32]. These results evidenced that thermal pretreatments are strain specific and thus, at the same temperature applied, different methane yields enhancement can be attained among the different biomass used. Higher temperatures $\left(130{ }^{\circ} \mathrm{C}\right.$ for $15-30 \mathrm{~min}$ ) were also tested, resulting in $28 \%$ methane yield increase when compared to a raw biomass composed by a mixture of green algae (Stigeoclonium sp. and Monoraphidium sp.) and diatoms (Nitzschia) (105 $\mathrm{mL} \mathrm{CH}_{4} / \mathrm{g} \mathrm{VS}_{\mathrm{in}}$ ) [31]. Due to the potential formation of Maillard compounds at higher temperatures, moderate temperatures in the range of $80-120{ }^{\circ} \mathrm{C}$ are most widely tested. Moreover, thermal pretreatments have been tested not only in batch mode, but also in semicontinuous mode. Méndez et al. [33] reported a methane yield enhancement of 1.5-fold compared to raw Chlorella biomass ( $84 \mathrm{~mL} \mathrm{CH}_{4} / \mathrm{g} \mathrm{COD}_{\text {in }}$ ) when using $120^{\circ} \mathrm{C}$ for $40 \mathrm{~min}$ for feeding a Completely Stirred Tank Reactor (CSTR). Although no common inhibitors were identified, the results obtained in the CSTR were considerably lower (50\% less) than the ones obtained in batch mode digestion. This experimentation corroborated the need to test each pretreatment in different feeding modes. Although thermal pretreatments normally present positive results in terms of methane yield, the values attained are very diverse depending on different variables such as the pretreated biomass, temperature, pretreatment time employed and operation mode during the digestion. Moreover, as mentioned above, these methods involved some drawbacks such as the formation of recalcitrant compounds that could potentially decrease the performance of the process [34,35].

Mechanical pretreatments are commonly employed to disrupt different kind of organic substrates in industrial processes [44,45]. Ultrasound treatment has been applied to disrupt microalgae cell wall in different bioprocess devoted to biofuel production, such as ethanol production from Chlorella biomass [46] and biodiesel generation from Spirulina biomass [47]. In the case of anaerobic digestion, ultrasound pretreatment has also shown positive results in terms of methane yield enhancement. González-Fernández et al. [43] applied $128.9 \mathrm{~kJ} / \mathrm{g}$ TS at $85^{\circ} \mathrm{C}$ and $30 \mathrm{~min}$ to enhance methane yield of Scenedesmus biomass from $81 \mathrm{~mL} \mathrm{CH}_{4} / \mathrm{g} \mathrm{COD}_{\text {in }}$ to $153 \mathrm{~mL} \mathrm{CH}_{4} / \mathrm{g} \mathrm{COD}_{\text {in }}$ (87\% enhancement). Nevertheless, those authors also pointed out the fact that ultrasound application is having associated an increase in temperature which also acts as a pretreatment. As a matter of fact, when it comes to the pretreatment of Scenedesmus sp., the benefits of ultrasound application were rather questionable compared to the enhancement in methane yield attained only with the application of temperature. Ultrasound pretreatment $(26.7 \mathrm{KJ} / \mathrm{g}$ TS for $30 \mathrm{~min}$ ) was also applied to Monoraphidium sp. and Stigeoclonium sp. biomass and their methane yields were enhanced from $105 \mathrm{~mL} \mathrm{CH}_{4} / \mathrm{g} \mathrm{COD}_{\text {in }}$ to $196 \mathrm{~mL} \mathrm{CH}_{4} / \mathrm{g} \mathrm{COD}_{\text {in }}$ [42]. When testing different energy inputs $(10 ; 27 ; 40 ; 57 \mathrm{KJ} / \mathrm{g}$ TS), applied to different mixtures of microalgae biomass (mixture A: 40\% Chlamydomonas, 20\% Scenedesmus and $40 \%$ Nannocloropsis; mixture B: 58\% Acutodesmus obliquus, 36\% Oocystis sp., 1\% Phormidium and 5\% Nitzschia sp; Mixture C: Microspora $\approx 100 \%$ ), an increase in methane yield ranging from 6 to $24 \%$ at $10 \mathrm{MJ} / \mathrm{kg}$ TS was determined, while higher energy inputs did not report any significant increase [34]. Despite all those positive results in terms of methane yields enhancement, the main limitation of ultrasound 
pretreatment is the high energy input required when compared to thermal, chemical or biological methods [21].

Chemical methods are often combined with heat pretreatment. Thermochemical pretreatments have been less employed than thermal and mechanical pretreatments due to its potential toxicity for the anaerobes. Cell wall disruption with alkali and acid pretreatments has been tested with positive results for the production of ethanol, butanol and biomethane when using microalgae biomass as a feedstock $[48,49]$. Studies related to microalgae biomass solubilization using thermo-alkaline methods include for instance the use of reagents such as $\mathrm{NaOH}$ or $\mathrm{CaO}$. Different doses of $\mathrm{CaO}(4$ and $10 \%$ $w / w)$ and different temperatures $\left(25,55\right.$ and $\left.72{ }^{\circ} \mathrm{C}\right)$ resulted in maximum proteins and carbohydrates solubilization of $32.4 \%$ and $31.4 \%$, respectively, and methane yield enhancement of $25 \%$ compared to the raw biomass $\left(260 \mathrm{~mL} \mathrm{CH}_{4} / \mathrm{g} \mathrm{VS}_{\text {in }}\right)$ at the highest temperature and lime dose tested $\left(72{ }^{\circ} \mathrm{C}\right.$ and $10 \% w / w)$ [50]. When using $\mathrm{NaOH}(0.5,2$ and $5 \% v / v)$ in Chlorella and Scenedesmus biomass, the conducted experiments revealed that despite of the biomass solubilisation, the methane yield enhancement was really low $(10 \%$, [36]). Thermo-acid pretreatments have been less employed than thermo-alkali. For instance, Chlorella biomass was heated at $120^{\circ} \mathrm{C}$ either for $20 \mathrm{~min}$ and $40 \mathrm{~min}$. Sulphuric acid addition combined with $120^{\circ} \mathrm{C}$ for 40 min enhanced carbohydrates solubilization by 7 -fold, although no solubilization of the protein fraction was reported. In terms of methane production, this thermo-acid pretreatment improved the methane yield from the untreated biomass from $139 \mathrm{~mL}$ $\mathrm{CH}_{4} \mathrm{~g} / \mathrm{COD}_{\text {in }}$ to $230 \mathrm{~mL} \mathrm{CH}_{4} \mathrm{~g} / \mathrm{COD}_{\text {in }}$ [51]. Since anaerobic digestion is taking place at around $\mathrm{pH}$ 7 , one of the main limitations of chemical pretreatments is the need to readjust the $\mathrm{pH}$ previously to the digestion. In this manner, chemical costs limit the use of these pretreatments. Moreover, some of the chemicals need to be removed previously to the anaerobic digestion as they can be toxic for anaerobes [27].

In conclusion, high energy demanding pretreatment methods report high values in terms of methane yield. However, they are energetically unbalanced. This means that the energy required to carry out the pretreatment is higher than the one obtained in form of biogas. This is why research has been directed towards the use of low energy demanding pretreatments

\subsection{Low Energy Demanding Pretreatments}

Compared to other pretreatments, the biological approach presents some advantages such as lower energy demand and high specificity [37]. These pretreatments include the use of suitable enzymes or microorganisms to hydrolyze microalgae biomass. Information about the cell wall composition is scarce, but necessary in order to select the most suitable enzyme for the pretreatment. For that reason, a wide range of biocatalysts have been tested. In principle, given the similarities between higher plants and microalgae, the most studied catalysts are carbohydrases. Among them, cellulases, hemicellulases, amylases and pectinases are the most tested ones [37,52]. Some other enzymatic cocktails employed for microalgae biomass hydrolysis include lysozyme (catalyzing the hydrolysis of 1,4-beta-linkages between $N$-acetylmuramic acid and $N$-acetyl-D-glucosamine residues in peptidoglycan [53]), proteases (hydrolyzing peptide bonds [39]) and laccases [25]. Overall, the best results have been evidenced by adding commercial proteases cocktails. For instance, carbohydrases and proteases were compared hydrolyzing Chlamydomonas reinhardtii and Chlorella vulgaris [38]. Enzyme doses applied for carbohydrases and proteases were $0.3 \mathrm{~mL} / \mathrm{g}$ DW and $0.2 \mathrm{~mL} / \mathrm{g}$ DW, respectively. The enzymatic pretreatment lasted for $5 \mathrm{~h}$ and results obtained after carbohydrases addition were $86 \%$ and $96 \%$ carbohydrate solubilization for C. vulgaris and C. reindhartii while in the case of protease addition both biomass resulted in $96 \%$ protein solubilization. However, the authors pointed out that despite of the high carbohydrate solubilization, only a $14 \%$ enhancement methane yield was observed in Chlorella biomass, whereas no improvement was observed in Chlamydomonas. In the case of protease pretreated biomass, methane yield was enhanced by $51 \%$ in the C. vulgaris and $7 \%$ for $C$. reindhartii. The reason for the low methane yield enhancement recorded for $C$. reindhartii was due to the inherent high anaerobic biodegradability of this strain $\left(75 \%, 263 \mathrm{~mL} \mathrm{CH}_{4} \mathrm{~g} / \mathrm{COD}_{\text {in }}\right)$. Methane yield is limited 
by the inherent methane yield that the biomass can attain. However, the kinetics might be enhanced by the use of pretreatments. More specifically, methane yield might be enhanced by protease pretreatment in the range of 1.07 to 6.3 fold depending on the targeted microalgae biomass within 10-15 days of digestion $[38,40]$.

An alternative to improve economically the enzymatic pretreatment and avoid the addition of high cost cocktails is the addition of hydrolytic secretomes released by other microorganisms. For instance, $0.7 \mathrm{~g} / \mathrm{L}$ of cellulase-secreting bacteria was added to Chlorella vulgaris for $48 \mathrm{~h}$ resulting in an increase of $18 \%$ organic matter solubilization and 2-fold methane yield compared to the raw biomass [54]. Non-specific extracellular enzymes of Anthracophyllum discolor were employed to disrupt the cell wall of Botryococcus braunii, resulting in an improvement of $60 \%$ methane yield, when enzymatic concentration of $1000 \mathrm{U} / \mathrm{mL}$ was applied [55]. Likewise, cellulolytic marine bacteria were applied to Botryococcus braunii and Nannochloropsis gaditana biomass 1:1 ratio DW resulting in a methane enhancement of $140 \%$ and $150 \%$, respectively compared to the raw biomass [56].

As it is observed in Table 1, almost all tested pretreatments improved methane production yields although a direct linkage between solubilization and methane enhancement still requires in-depth research in continuous systems to determine the energy balance and costs of the overall process [57]. Even though this pretreatment is economically unfeasible yet, enzymatic pretreatments, targeting at specific molecules, could provide important information in order to identify which is the microalgae macromolecule hampering biogas production when using this biomass [23].

\section{Biological Approach to Enhance Biogas Production: Enzymatic Pretreatment}

Opposite to other pretreatments, biological reactions show high selectivity and absence of inhibitory compounds. Biocatalysts do not only disrupt the cell wall, but they also hydrolyze the macromolecules during biological pretreatment. As it was indicated above, these methods are energetically competitive since they require soft temperatures and smooth shaking. Different parameters must be taken into account such as $\mathrm{pH}$, temperature, enzyme dose, and exposure time [21]. Given the different macromolecular composition, structural features and cell wall composition among microalgae strains, a wide range of biocatalysts can be used. Despite of the high economic cost of the enzymatic cocktails, the use of biocatalysts can provide crucial information to identify the macromolecule hampering anaerobic digestion of microalgae biomass. Moreover, the costs could be reduced either by in situ enzymes production $[54,58]$ or by particular enzymes secreted by bacteria and fungi via sludge bioaugmentation $[23,59,60]$.

\subsection{Carbohydrases}

Carbohydrases are in charge of hydrolysing carbohydrates polymers present within the cell wall and inside the cells into simple sugars. Since it is believed that carbohydrates are the responsible of cell wall toughness, cellulaseshave been tested in microalgae biomass to enhance the hydrolysis. Cellulases from Trichoderma reseei were mixed with metal oxides to treat Chlorella biomass resulting in glucose yield of $91 \%$ of the theoretical maximum [61]. Furthermore, enzymatic cocktails aimed at degrading the compartmentalized cell material such as amylases and amyloglucosidases have been tested to promote the efficiency of the hydrolysis step. As a matter of fact, a combination of amylases and cellulases was tested to degrade the cell wall and the cell material with acid hydrolysis in Chlorella sorokiniana, Nannochloropsis gaditana, and Scenedesmus. This treatment produced a sugar release of $128 \mathrm{mg} / \mathrm{g}$ DW, $129 \mathrm{mg} / \mathrm{g}$ DW and $60 \mathrm{mg} / \mathrm{g}$ DW, respectively against control values for the different biomass (70 mg/g DW, $20 \mathrm{mg} / \mathrm{g}$ DW and $25 \mathrm{mg} / \mathrm{g}$ DW) [62]. Carbohydrases have also been tested to facilitate lipid extraction by using exoglucanase, endoglucanase, xylanase and laccase produced by different biomass-degrading bacteria, improving lipid extraction up to 40\% [63]. All those studies are mainly focused on carbohydrates solubilisation while, only recently, the biomass subjected to carbohydrases has been investigated for biogas production purposes. Ometto et al. [9] tested different enzymatic cocktails on three different biomass, namely Scenedesmus obliquus, Chlorella sorokiniana and Arthrospira 
maxima [5]. Out of the tested enzymatic cocktails, mixtures of cellulase plus pectinase and esterase plus protease were the most effective catalysts for organic matter hydrolysis of all three biomass. In the same manner, commercial cocktails hydrolyzing the carbohydrate fraction such as Viscozyme, Celluclast and Pectinase (from Novozymes, Bagsværd, Denmark) have been employed in C. vulgaris and Scenedesmus. The use of Viscozyme provided carbohydrate fraction solubilization of $84 \%$ and $36 \%$ for C. vulgaris and Scenedesmus respectively, while the methane yield enhancement was 1.2-fold for both of them, despite of the different biomass composition and strain [41]. This experimentation suggested that the carbohydrate fraction cannot be understood as a whole to elucidate the relation between solubilization efficiency and the methane yield achievable. Instead of this, an in-depth research must be done concerning the carbohydrates composition of microalgae cell wall.

\subsection{Lipases}

When compared to other macromolecular constituents, lipids could be very useful substrates for anaerobic digestion due to its high potential methane yield. More specifically, theoretical methane yield for lipids is $1.014 \mathrm{~L} \mathrm{CH}_{4} / \mathrm{g}$ VS compared to 0.496 and $0.415 \mathrm{~L} \mathrm{CH}_{4} / \mathrm{g}$ VS for proteins and carbohydrates, respectively [10]. However, instability of the system can easily occur due to the formation of long chain fatty acids when lipids are hydrolyzed [64]. As a matter of fact, studies are mainly focused on the optimal concentration of lipids that makes possible to carry out anaerobic digestion without inhibition. In this way, it has been highlighted that lipid fraction should not be over $30 \%$ to avoid process inhibition [65]. To overcome such an inhibition, different strategies have been developed. For instance, Palatsi et al. [66] tested different recovery strategies to reduce the negative effect of long chain fatty acids by using different feeding patterns and adsorbents addition. Despite of the high lipid potential to enhance methane yield, microalgae biomass grown in wastewater does not present high lipid content $[67,68]$. At this point, it should be stressed that microalgae grown in residual effluents is the only feasible way to produce biofuel using this feedstock. In this manner, really limited information on lipases treatment of microalgae biomass for biogas production can be found in literature. For instance, an enzymatic mixture containing protease, $\alpha$-amylase, xylanase, lipase and cellulase employed for Rhizoclonium biomass (filamentous green algae) hydrolysis resulted in $40 \%$ yield enhancement [69]. In this case, the mixture of enzymes made difficult the identification of the enzymatic activity responsible for such an enhancement. Ometto et al. [9] also tested esterases in different lipid rich microalgae biomass. Moreover, this investigation reported the use of esterases alone and the mixture of esterases and proteases. No biogas production was attempted for the biomass pretreated with esterases alone and thus, no conclusion could be withdrawn. Nevertheless, their work revealed that this later enzymatic mixture supported much higher organic matter solubilization than the values attained for esterases application alone, highlighting the importance of microalgae proteins.

\subsection{Proteases}

Microalgae biomass is normally prevailing in protein content. As a matter of fact, this polymer might represent approximately $40-60 \%$ of the microalgae dry weight $[24,70]$. Protein fraction might be degraded by proteases since they hydrolyze peptides into amino acids. The use of proteases is receiving particular interest in last years, especially in combination with other pretreatments or other commercial enzymatic cocktails [71,72]. Some examples on the use of proteases in different microalgae biomass were evaluated in terms of organic matter solubilization and methane yields [38-40]. In the context of anaerobic digestion, methane yields of $C$. vulgaris and Scenedesmus sp. were enhanced by 2.6-fold and 1.53-fold, respectively, when pretreated with protease [39]. It is important to note that those results were attained with proteins rich biomass. More specifically, Chlorella vulgaris exhibited $64 \%$ protein and $22 \%$ carbohydrate content. When dealing with carbohydrate rich C. vulgaris biomass (39.6\%), protease hydrolysis efficiency (54\%) displayed higher organic matter values than carbohydrolase hydrolysis (approx. 26\%). The different effect of both enzymatic cocktails was also observed in the methane yields attained by both pretreated biomass. In that case, methane yield achieved with the biomass 
pretreated with proteases was $137 \mathrm{~mL} \mathrm{CH}_{4} \mathrm{~g} / \mathrm{COD}_{\text {in }}$ while $65 \mathrm{~mL} \mathrm{CH}_{4} \mathrm{~g} / \mathrm{COD}_{\text {in }}$ was obtained for the biomass pretreated with carbohydrases [40]. This fact showed that even working with carbohydrate rich C. vulgaris, the proteolytic cocktail supported high organic matter hydrolysis and methane yields.

Comparison of different studies regarding enzymatic pretreatments suggested that proteins are the molecules that hindered the access of anaerobic bacteria to microalgae organic matter in the anaerobic digestion process to a greater extent than carbohydrates or lipids. Therefore, the protein fraction has been carefully analyzed during the anaerobic digestion process of microalgae biomass in the subsequent section

\section{Biomass Proteins in Anaerobic Digestion of Microalgae}

Anaerobic digestion is divided in four different stages including hydrolysis, acidogenesis, acetogenesis and methanogenesis (Figure 1). When protein rich microalgae are subjected to anaerobic digestion, the bioprocess can be affected at different stages.

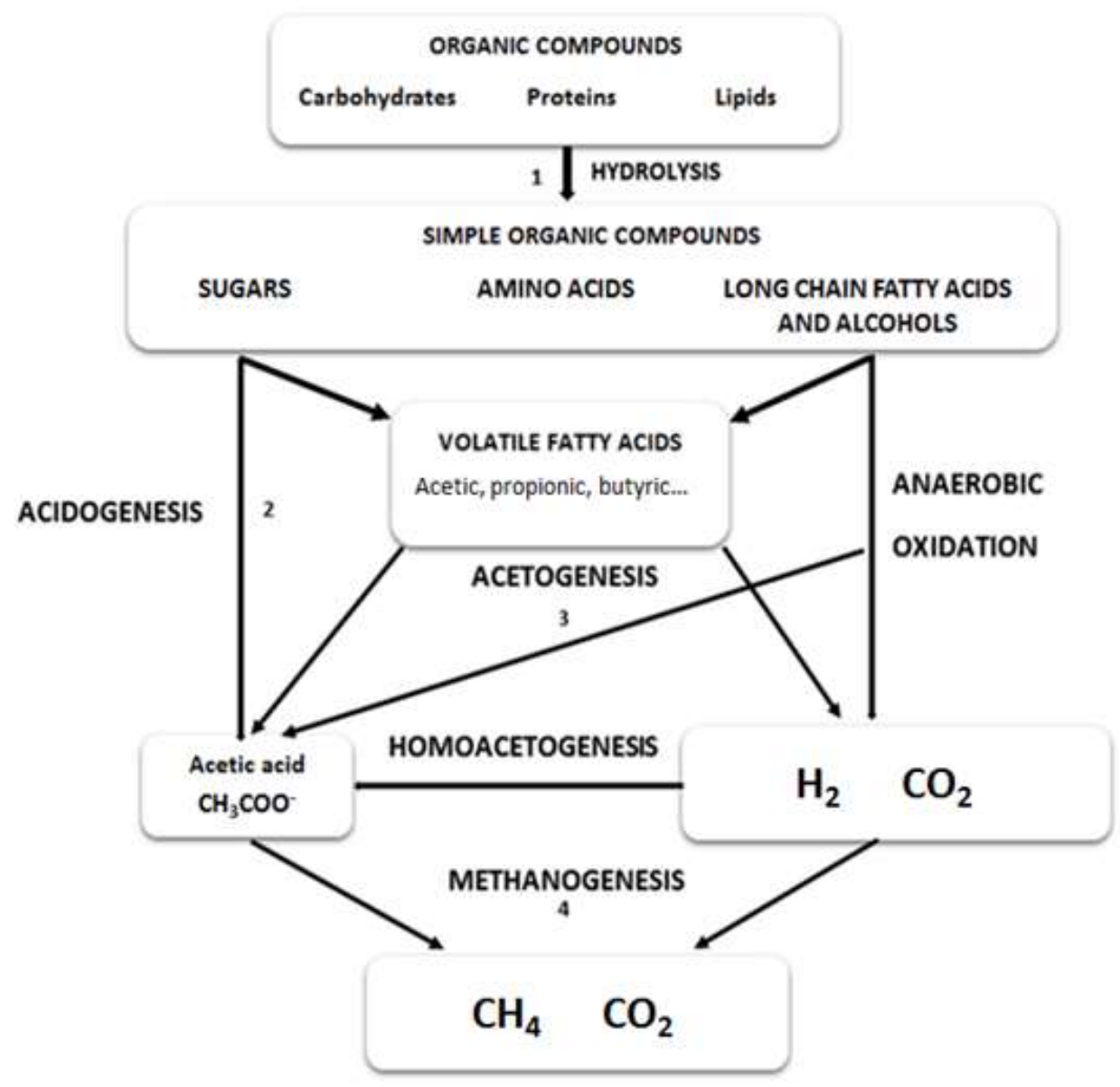

Figure 1. Reactive scheme for the anaerobic digestion of polymeric microalgal biomass.

Anaerobic degradation of proteins and lipids has not been investigated in depth compared to that of carbohydrates. Proteins are hydrolyzed to aminoacids by extracellular enzymes. Anaerobic and facultatively anaerobic bacteria, mainly Clostridium, are responsible of aminoacids fermentation. Clostridia obtain energy by coupled oxidation-reduction reaction between aminoacids via the so-called Stickland reaction. This reaction entails the oxidation (dehydrogetation) of one aminoacid and the reduction of a second aminoacids (hydrogenation) (Figure 2). 


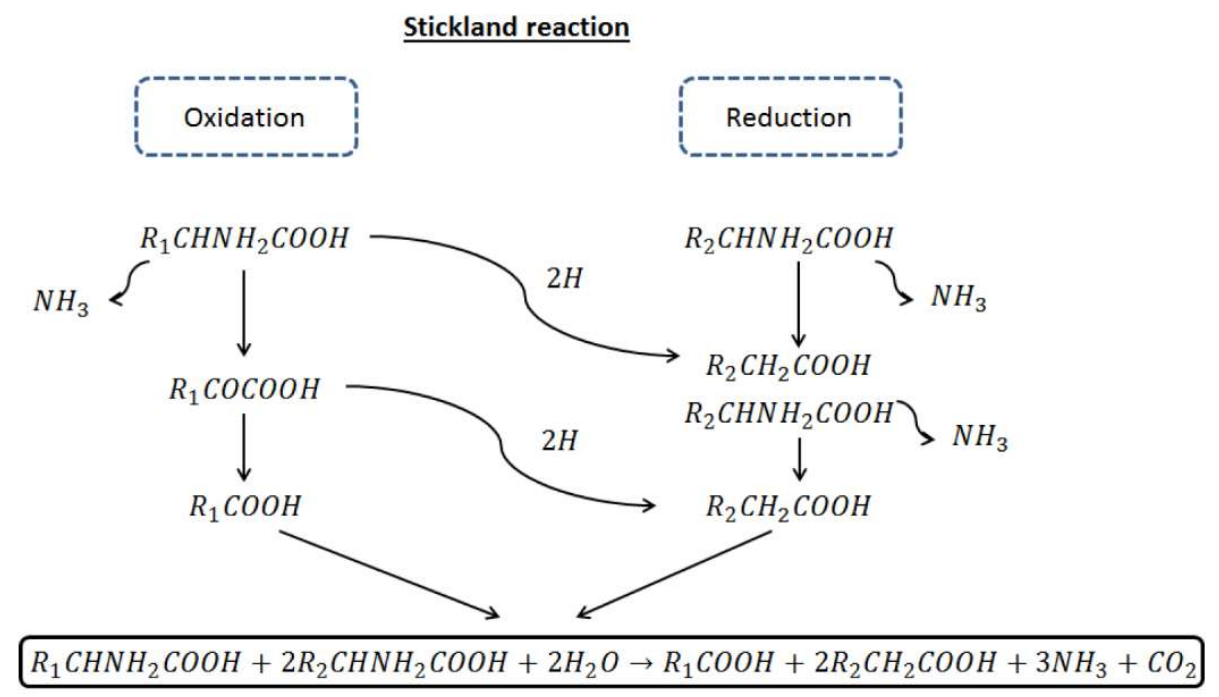

Figure 2. Stickland reactions scheme.

Aminoacids can act as electron acceptors or donors. In the first case, the aminoacid form a carboxylic acid with one carbon shorter than the original acid (e.g alanine to acetate) while when acting and electron acceptor, it retains the carbon to form a carboxylic acid with the same chain length as the original aminoacid (e.g., glycine to acetate). The aminoacid is de-ammonified by anaerobic oxidation, yielding volatile fatty acids and hydrogen, as shown in Table 2 [73].

Table 2. Aminoacid products based on Stickland reaction (modified from [73]).

\begin{tabular}{ccccccccccc}
\hline Amino Acid & Formula & HAc & HProp & HBu & HVa & IN & IC & Other & $\mathbf{H}_{2}$ & ATP \\
\hline Arginine & $\mathrm{C}_{6} \mathrm{H}_{14} \mathrm{O}_{2} \mathrm{~N}_{4}$ & 0.5 & 0.5 & 0 & 0.5 & 4 & 1 & 0 & -1 & 1 \\
Histidine & $\mathrm{C}_{6} \mathrm{H}_{9} \mathrm{O}_{2} \mathrm{~N}_{3}$ & 1 & 0 & 0.5 & 0 & 3 & 1 & 1 & 0 & 2 \\
Lysine & $\mathrm{C}_{6} \mathrm{H}_{14} \mathrm{O}_{2} \mathrm{~N}_{2}$ & 1 & 0 & 1 & 0 & 2 & 0 & 0 & 0 & 1 \\
Tyrosine & $\mathrm{C}_{9} \mathrm{H}_{11} \mathrm{O}_{3} \mathrm{~N}$ & 1 & 0 & 0 & 0 & 1 & 1 & 0.882 & 1 & 1 \\
Tryptophan & $\mathrm{C}_{11} \mathrm{H}_{12} \mathrm{O}_{3} \mathrm{~N}$ & 0 & 0 & 0 & 0 & 1 & 1 & 1.471 & 2 & 1 \\
Phenylalanine & $\mathrm{C}_{9} \mathrm{H}_{11} \mathrm{O}_{2} \mathrm{~N}$ & 0 & 0 & 0 & 0 & 1 & 1 & 1.176 & 2 & 1 \\
Cysteine & $\mathrm{C}_{3} \mathrm{H}_{6} \mathrm{O}_{2} \mathrm{NS}$ & 1 & 0 & 0 & 0 & 1 & 1 & 0 & 1 & 1 \\
Methionine & $\mathrm{C}_{5} \mathrm{H}_{11} \mathrm{O}_{2} \mathrm{NS}$ & 0 & 1 & 0 & 0 & 1 & 1 & 0 & 1 & 1 \\
Threonine & $\mathrm{C}_{4} \mathrm{H}_{9} \mathrm{O}_{3} \mathrm{~N}$ & 1 & 0 & 0.5 & 0 & 1 & 0 & 0 & -1 & 1 \\
Serine & $\mathrm{C}_{3} \mathrm{H}_{7} \mathrm{O}_{3} \mathrm{~N}$ & 1 & 0 & 0 & 0 & 1 & 1 & 0 & 1 & 1 \\
Leucine/Isoleucine & $\mathrm{C}_{6} \mathrm{H}_{13} \mathrm{O}_{2} \mathrm{~N}$ & 0 & 0 & 0 & 1 & 1 & 1 & 0 & 2 & 1 \\
Valine & $\mathrm{C}_{5} \mathrm{H}_{11} \mathrm{O}_{2} \mathrm{~N}$ & 0 & 0 & 1 & 0 & 1 & 1 & 0 & 2 & 1 \\
Glutamine & $\mathrm{C}_{5} \mathrm{H}_{9} \mathrm{O}_{4} \mathrm{~N}$ & 1 & 0 & 0.5 & 0 & 1 & 1 & 0 & 0 & 2 \\
Aspartate & $\mathrm{C}_{4} \mathrm{H}_{7} \mathrm{O}_{4} \mathrm{~N}$ & 1 & 0 & 0 & 0 & 1 & 2 & 0 & 2 & 2 \\
Glycine & $\mathrm{C}_{2} \mathrm{H}_{5} \mathrm{O}_{2} \mathrm{~N}$ & 1 & 0 & 0 & 0 & 1 & 0 & 0 & -1 & 0 \\
Alanine & $\mathrm{C}_{3} \mathrm{H}_{7} \mathrm{O}_{2} \mathrm{~N}$ & 1 & 0 & 0 & 0 & 1 & 1 & 0 & 2 & 1 \\
Proline & $\mathrm{C}_{5} \mathrm{H}_{9} \mathrm{O}_{2} \mathrm{~N}$ & 0.5 & 0.5 & 0 & 0.5 & 1 & 0 & 0 & -1 & 0 \\
\hline
\end{tabular}

\subsection{The Relevance of Microalgae Proteins in the Hydrolysis Stage of Anaerobic Digestion}

The first biological process involved in anaerobic digestion is hydrolysis, which is the limiting step and its effectiveness is crucial for the overall process $[9,74]$. Focusing on proteins, they are hydrolyzed into amino acids by extracellular enzymes secreted by different bacteria such as Clostridium, Vibrio, Peptococcus, Bacillus, Proteus, or Bacteroides [23]. As reviewed above, research devoted to microalgae digestion conducted over last years showed higher methane production in protease pretreated biomass compared to raw biomass and biomass treated with carbohydrases [40]. Methane production of protease pretreated $C$. vulgaris was enhanced by $51 \%$ compared to the raw biomass, showing the benefits of having proteins in the soluble phase. Similarly, methane yield enhancement $(37 \%)$ of 
cyanobacteria was also attributed to the proteolytic activity developed upon biomass storage [74]. Even though protease addition has revealed the importance of microalgae proteins in microalgae digestion, it is clear that the use of commercial cocktails would not make biogas production profitable. In this manner, the use of commercial proteases helped in the identification of the macromolecule opposing more resistance to an optimal anaerobic digestion but cheaper alternatives should be investigated for avoiding the addition of commercial enzymes. Two main strategies can be applied for such a purpose. The first one entails the use of in-situ released enzymes by fungi or bacteria. Through the so-called bioaugmentation, microorganisms can be added to the anaerobic sludge used as degradation consortium. In this manner, once identified the microorganisms producing the enzymatic cocktail required for the targeted microalgae biomass, it can be added to the anaerobic sludge. Obviously, the appropriate microbial species should be carefully selected to be effective, not only for microalgae hydrolysis, but also to be viable and present good activity within the anaerobic microbiome. The potential of bioaugmentation, including the main benefits and limitations, has been recently reviewed [75]. This approach has been applied in more conventional substrates while literature available on bioaugmentation strategies devoted to microalgae anaerobic digestion is scarce. Nevertheless, this strategy was successfully applied to improve methane production of C. vulgaris biomass [60]. Those researchers showed an enhanced methane yield (18-38\%) after adding Clostridium thermocellum at various inoculum ratios to degrade the carbohydrate fraction of microalgae biomass. Likewise, the same bacteria, $C$. thermocellum, was reported to enhance methane yield (18-38\%) when degrading Haematococcus pluvialis. Therefore, this acidogenic phase bacteria is nowadays considered as a promising biotechnological tool to improve anaerobic digestion of microalgae through bioaugmentation.

The second alternative to increase the hydrolytic activity of anaerobic sludge is the use of metals. The addition of trace metals as micronutrients have been proven to stimulate methane production. The dosing needs to be well balanced to support the desired microbial activity or growth rate above which the trace metals become inhibitory or toxic. These metals are essential in the anaerobic reactions, since most of them are part of the active site of enzymes. The effect on different trace metal on anaerobic digestion can be found elsewhere [76]. Even though the use of trace elements is beneficial in most cases, the response of the system is uncertain due to the complexity of the anaerobic digestion process. It is recommended for substrates which initially have low trace element content. For instance, Kim et al. [77] evaluated the effect of trace elements at different range temperatures highlighting the benefits of using Fe, Co. or Ni for the hydrolysis step due to the increase of COD solubilization and organic acids production.

\subsection{The Relevance of Microalgae Proteins in the Methanogenesis Stage of Anaerobic Digestion}

Out of the subsequent stages involved in anaerobic digestion, hydrogen and acetic acid are converted to methane gas and carbon dioxide during methanogenesis. This last stage is performed by archaea. When compared to anaerobic bacteria involved in anaerobic digestion, archaea are more sensitive to toxic compounds and also exhibit lower growth rates. Acidifiers present ten to twenty-fold higher growth rates and five-fold conversion rates than methanogens $[1,69]$. With regard to their sensibility toward toxic compounds, methanogens exhibit low tolerance against ammonium nitrogen. Depending on digester $\mathrm{pH}$ and operation temperature, the ammonium/ammonia equilibrium might shift. This latter component has been claimed to be highly toxic for methanogens. Ammonia diffuses freely through the permeable membrane of methanogens cells causing changes in intracellular $\mathrm{pH}$ and resulting in potassium deficiency and/or proton imbalance [78]. Moreover, ammonium can also inhibit enzymes that are involved in methane production [79]. Yenigün and Demirel [80] reported inhibition of the methanogenesis stage at total ammonia nitrogen (TAN) and ammonia concentrations of $1700-1800 \mathrm{mg} / \mathrm{L}$ and $150 \mathrm{mg} / \mathrm{L}$, respectively. As a result, the high concentration of TAN $\left(\mathrm{NH}_{3}\right.$ and $\mathrm{NH}_{4}{ }^{+}$) can lead to volatile fatty acids accumulation. This last process involves acidification of the anaerobic broth, which in turns inhibits methanogens activity. Therefore, the main drawback of 
protein rich biomass, such as microalgae, during digestion is the high amount of nitrogen released in form of ammonium that can inhibit methane formation. In fact, this inhibition has been already evidenced by Mahdy et al. [38] during the digestion of protein rich Chlorella vulgaris. Those authors attributed the stepwise methane production decrease to the high nitrogen mineralization (77\%) taking place during the digestion of protease pretreated microalgae biomass. In this manner, microalgae proteins are not only limiting the hydrolysis stage of the anaerobic digestion but they might also be detrimental in methanogenesis stage. Similar to the developed strategies to overcome the negative effect of microalgae proteins in hydrolysis, some solutions have been proposed to overcome the issues that proteins might cause in methanogenesis during those last years of research.

To avoid inhibition by ammonium, different strategies can be implemented. One of them entails the use of nitrogen poor media for microalgae cultivation. Due to the low nitrogen availability in the medium, proteins accumulation is restricted while lipids and carbohydrates fractions become more abundant in the grown biomass [81,82]. Biogas production was modified using this method in different studies $[80,83]$. This strategy can be easily applied by using urban wastewater as culture media, which normally contains considerable lower nitrogen concentrations than synthetic salt media ( $\approx 60$ vs. $300-600 \mathrm{mg} \mathrm{N} / \mathrm{L}$ ). The benefit of this strategy has been evidenced recently using Spirulina biomass for biogas production [12]. Similar results were obtained with C. vulgaris, where a higher accumulation of carbohydrates $(40 \%)$ was observed when microalgae was grown in urban wastewater while only $22 \%$ was obtained in biomass grown in synthetic medium. Concomitantly with the increase in carbohydrates, protein biomass content was reduced (from 64 to 33\%) and thus, methane production was enhanced [40].

A second approach to avoid ammonium inhibition is through sludge bioaugmentation. This approach consists in introducing or enriching specific anaerobic microorganisms with special features. Thus, anaerobic microorganisms that are tolerant to high $\mathrm{NH}_{4}{ }^{+}$concentrations should be used within the anaerobic sludge to accomplish this goal. Although it is generally believed that total ammonia levels above $3 \mathrm{~g} / \mathrm{L}$ have toxic effect on the methanogens, the resistance of methanogens can be increased by exposing the microorganisms to high nitrogen concentrations [83]. The use ammonia tolerant inocula has been recently demonstrated as an efficient option for digestion of $C$. vulgaris and cattle manure [84]. In this study, the effectiveness of adapted methanogens resulted in a $33 \%$ methane yield increase. This approach allowed operating the digester at 3.7-4.2 $\mathrm{g} \mathrm{NH}_{4}{ }^{+}-\mathrm{N} / \mathrm{L}$. Tian et al. [85] operated an acclimation experiment in continuous anaerobic reactors fed with substrate rich in the protein fraction such as microalgae and cattle slurry manure. Results showed a stable biomethanization process despite of the high ammonium concentration $\left(10 \mathrm{~g} \mathrm{NH}_{4}{ }^{+}-\mathrm{N} / \mathrm{L}\right)$. Authors stressed the changes on the anaerobic population taking place as the responsible feature to handle high ammonium concentration. Even though this biological strategy is very promising, it is necessary to do further research due to the challenges that might arise such as the different behavior that the bioaugmented inocula under different operational conditions imposed in the reactors. Attention must be directed to microorganism's population since they might fail to thrive or be washed out from the reactors.

\section{Conclusions}

Anaerobic digestion of microalgae has been presented as a promising alternative for generation of bioenergy. The implementation of this process requires pretreatment of the rigid algae cell wall in order to make available the organic matter to anaerobes. Enzymatic pretreatment with proteases showed the best performance in terms of organic matter solubilization and methane production. This feature already highlighted the importance of proteins in the hydrolysis stage of anaerobic digestion. Solving this problem with protease addition could result in methanogens inhibition mediated by high ammonium concentrations reached during nitrogen mineralization. Two solutions are proposed to overcome potential inhibition, namely the reduction of nitrogen levels of microalgae biomass using a low nitrogen concentration culture media and the use of ammonium tolerant anaerobic inocula. This fact showed that protein embedded in microalgae cell wall might be responsible for their 
inherent low biodegradability. Microalgae proteins might be crucial not only in the hydrolytic phase but also during methanogenesis.

Author Contributions: J.A.M. and C.G.-F. were responsible for the manuscript preparation. M.B. was responsible for revising the manuscript. The final publication was prepared with contribution from all authors.

Acknowledgments: The authors wish to thank the Spanish Ministry of Economy and Competitiveness for the financial support provided through the grants ENE2013-45416-R and RYC-2014-16823 and the Community of Madrid for the support offered in the framework of the project INSPIRA-1 (S2013/ABI-2783).

Conflicts of Interest: The authors declare no conflict of interest.

\section{References}

1. Henze, M.; van Loosdrecht, M.C.M.; Ekama, G.A.; Brdjanovic, D. Biological Wastewater Treatment; IWA Publishing: London, UK, 2008.

2. Abdel-Raouf, N.; Al-Homaidan, A.A.; Ibraheem, I.B.M. Microalgae and wastewater treatment. Saudi J. Biol. Sci. 2012, 19, 257-275. [CrossRef] [PubMed]

3. Xin, C.; Addy, M.M.; Zhao, J.; Cheng, Y.; Cheng, S.; Mu, D.; Liu, Y.; Ding, R.; Chen, P.; Ruan, R. Comprehensive techno-economic analysis of wastewater-based algal biofuel production: A case study. Bioresour. Technol. 2016, 211, 584-593. [CrossRef] [PubMed]

4. Passos, F.; Gutiérrez, R.; Uggetti, E.; Garfí, M.; García, J.; Ferrer, I. Towards energy neutral microalgae-based wastewater treatment plants. Algal Res. 2017, 28, 235-243. [CrossRef]

5. Milledge, J.J.; Heaven, S. Energy Balance of Biogas Production from microalgae: Development of an energy and mass balance model. Curr. Biotechnol. 2015, 4, 554-567. [CrossRef]

6. Davis, R.; Aden, A.; Pienkos, P.T. Techno-economic analysis of autotrophic microalgae for fuel production. Appl. Energy 2011, 88, 3524-3531. [CrossRef]

7. Arashiro, L.T.; Montero, N.; Ferrer, I.; Acién, F.G.; Gómez, C.; Garfí, M. Life cycle assessment of high rate algal ponds for wastewater treatment and resource recovery. Sci. Total Environ. 2018, 622, 1118-1130. [CrossRef]

8. Muñoz, R.; Gonzalez-Fernandez, C. Microalgae-Based Biofuels and Bioproducts: From Feedstock Cultivation to End-Products; Woodhead Publishing Series in Energy; Elsevier Science: New York, NY, USA, 2017.

9. Ometto, F.; Quiroga, G.; Psenicka, P.; Whitton, R.; Jefferson, B.; Villa, R. Impacts of microalgae pre-treatments for improved anaerobic digestion: Thermal treatment, thermal hydrolysis, ultrasound and enzymatic hydrolysis. Water Res. 2014, 65, 350-361. [CrossRef] [PubMed]

10. Angelidaki, I.; Sanders, W. Assessment of the anaerobic biodegradability of macropollutants. Re/Views Environ. Sci. Bio/Technol. 2004, 3, 117-129. [CrossRef]

11. Sialve, B.; Bernet, N.; Bernard, O. Anaerobic digestion of microalgae as a necessary step to make microalgal biodiesel sustainable. Biotechnol. Adv. 2009, 27, 409-416. [CrossRef] [PubMed]

12. Markou, G.; Angelidaki, I.; Georgakakis, D. Carbohydrate-enriched cyanobacterial biomass as feedstock for bio-methane production through anaerobic digestion. Fuel 2013, 111, 872-879. [CrossRef]

13. Yu, W.-L.; Ansari, W.; Schoepp, N.G.; Hannon, M.J.; Mayfield, S.P.; Burkart, M.D. Modifications of the metabolic pathways of lipid and triacylglycerol production in microalgae. Microb. Cell Fact. 2011, 10, 91. [CrossRef] [PubMed]

14. Mata, T.M.; Martins, A.A.; Caetano, N.S. Microalgae for biodiesel production and other applications: A review. Renew. Sustain. Energy Rev. 2010, 14, 217-232. [CrossRef]

15. Fábregas, J.; Maseda, A.; Domínguez, A.; Otero, A. The cell composition of Nannochloropsis sp. changes under different irradiances in semicontinuous culture. World J. Microbiol. Biotechnol. 2004, 20, 31-35. [CrossRef]

16. Pancha, I.; Chokshi, K.; George, B.; Ghosh, T.; Paliwal, C.; Maurya, R.; Mishra, S. Nitrogen stress triggered biochemical and morphological changes in the microalgae Scenedesmus sp. CCNM 1077. Bioresour. Technol. 2014, 156, 146-154. [CrossRef] [PubMed]

17. Golueke, C.G.; Oswald, W.J.; Gotaas, H.B. Anaerobic digestion of algae. Appl. Microbiol. 1957, 5, 47-55. [PubMed]

18. Demuez, M.; Mahdy, A.; Tomás-Pejó, E.; González-Fernández, C.; Ballesteros, M. Enzymatic cell disruption of microalgae biomass in biorefinery processes. Biotechnol. Bioeng. 2015, 112, 1955-1966. [CrossRef] [PubMed] 
19. De Leeuw, J.W.; Versteegh, G.J.M.; van Bergen, P.F. Biomacromolecules of algae and plants and their fossil analogues. In Plants and Climate Change; Rozema, J., Aerts, R., Cornelissen, H., Eds.; Springer: Dordrecht, The Netherlands, 2006; pp. 209-233.

20. Kodner, R.B.; Summons, R.E.; Knoll, A.H. Phylogenetic investigation of the aliphatic, non-hydrolyzable biopolymer algaenan, with a focus on green algae. Org. Geochem. 2009, 40, 854-862. [CrossRef]

21. Passos, F.; Uggetti, E.; Carrère, H.; Ferrer, I. Pretreatment of microalgae to improve biogas production: A review. Bioresour. Technol. 2014, 172, 403-412. [CrossRef] [PubMed]

22. Klassen, V.; Blifernez-Klassen, O.; Wobbe, L.; Schluter, A.; Kruse, O.; Mussgnug, J.H. Efficiency and biotechnological aspects of biogas production from microalgal substrates. J. Biotechnol. 2016, 234, 7-26. [CrossRef] [PubMed]

23. Gonzalez-Fernandez, C.; Sialve, B.; Molinuevo-Salces, B. Anaerobic digestion of microalgal biomass: Challenges, opportunities and research needs. Bioresour. Technol. 2015, 198, 896-906. [CrossRef] [PubMed]

24. González-Fernández, C.; Sialve, B.; Bernet, N.; Steyer, J.-P. Impact of microalgae characteristics on their conversion to biofuel. Part II: Focus on biomethane production. Biofuels Bioprod. Biorefin. 2012, 6, 205-218. [CrossRef]

25. Hom-Diaz, A.; Passos, F.; Ferrer, I.; Vicent, T.; Blánquez, P. Enzymatic pretreatment of microalgae using fungal broth from Trametes versicolor and commercial laccase for improved biogas production. Algal Res. 2016, 19, 184-188. [CrossRef]

26. Cordova, O.; Passos, F.; Chamy, R. Physical pretreatment methods for improving microalgae anaerobic biodegradability. Appl. Biochem. Biotechnol. 2017. [CrossRef] [PubMed]

27. Pandey, A.; Negi, S.; Binod, P.; Larroche, C. Pretreatment of Biomass: Processes and Technologies; Elsevier Science: New York, NY, USA, 2014.

28. Zhen, G.; Lu, X.; Kato, H.; Zhao, Y.; Li, Y.Y. Overview of pretreatment strategies for enhancing sewage sludge disintegration and subsequent anaerobic digestion: Current advances, full-scale application and future perspectives. Renew. Sustain. Energy Rev. 2017, 69, 559-577. [CrossRef]

29. Passos, F.; Ferrer, I. Microalgae conversion to biogas: Thermal pretreatment contribution on net energy production. Environ. Sci. Technol. 2014, 48, 7171-7178. [CrossRef] [PubMed]

30. González-Fernández, C.; Méndez, L.; Ballesteros, M.; Tomás-Pejó, E. Hydrothermal Processing of Microalgae. In Hydrothermal Processing in Biorefineries: Production of Bioethanol and High Added-Value Compounds of Second and Third Generation Biomass; Ruiz, H.A., Hedegaard Thomsen, M., Trajano, H.L., Eds.; Springer: Cham, The Netherlands, 2017.

31. Passos, F.; Carretero, J.; Ferrer, I. Comparing pretreatment methods for improving microalgae anaerobic digestion: Thermal, hydrothermal, microwave and ultrasound. Chem. Eng. J. 2015, 279, 667-672. [CrossRef]

32. Wang, M.; Lee, E.; Dilbeck, M.P.; Liebelt, M.; Zhang, Q.; Ergas, S.J. Thermal pretreatment of microalgae for biomethane production: Experimental studies, kinetics and energy analysis. J. Chem. Technol. Biotechnol. 2017, 92, 399-407. [CrossRef]

33. Mendez, L.; Mahdy, A.; Ballesteros, M.; González-Fernández, C. Biomethane production using fresh and thermally pretreated Chlorella vulgaris biomass: A comparison of batch and semi-continuous feeding mode. Ecol. Eng. 2015, 84, 273-277. [CrossRef]

34. Alzate, M.E.; Muñoz, R.; Rogalla, F.; Fdz-Polanco, F.; Pérez-Elvira, S.I. Biochemical methane potential of microalgae: Influence of substrate to inoculum ratio, biomass concentration and pretreatment. Bioresour. Technol. 2012, 123, 488-494. [CrossRef] [PubMed]

35. Mendez, L.; Mahdy, A.; Demuez, M.; Ballesteros, M.; González-Fernández, C. Effect of high pressure thermal pretreatment on Chlorella vulgaris biomass: Organic matter solubilisation and biochemical methane potential. Fuel 2014, 117, 674-679. [CrossRef]

36. Mahdy, A.; Mendez, L.; Ballesteros, M.; González-Fernández, C. Autohydrolysis and alkaline pretreatment effect on Chlorella vulgaris and Scenedesmus sp. methane production. Energy 2014, 78, 48-52. [CrossRef]

37. Carrillo-Reyes, J.; Barragán-Trinidad, M.; Buitrón, G. Biological pretreatments of microalgal biomass for gaseous biofuel production and the potential use of rumen microorganisms: A review. Algal Res. 2016, 18, 341-351. [CrossRef]

38. Mahdy, A.; Mendez, L.; Ballesteros, M.; González-Fernández, C. Enhanced methane production of Chlorella vulgaris and Chlamydomonas reinhardtii by hydrolytic enzymes addition. Energy Convers. Manag. 2014, 85, 551-557. [CrossRef] 
39. Mahdy, A.; Mendez, L.; Ballesteros, M.; González-Fernández, C. Protease pretreated Chlorella vulgaris biomass bioconversion to methane via semi-continuous anaerobic digestion. Fuel 2015, 158, 35-41. [CrossRef]

40. Mahdy, A.; Ballesteros, M.; González-Fernández, C. Enzymatic pretreatment of Chlorella vulgaris for biogas production: Influence of urban wastewater as a sole nutrient source on macromolecular profile and biocatalyst efficiency. Bioresour. Technol. 2016, 199, 319-325. [CrossRef] [PubMed]

41. Mahdy, A.; Mendez, L.; Tomás-Pejó, E.; del Mar Morales, M.; Ballesteros, M.; González-Fernández, C. Influence of enzymatic hydrolysis on the biochemical methane potential of Chlorella vulgaris and Scenedesmus sp. J. Chem. Technol. Biotechnol. 2016, 91, 1299-1305. [CrossRef]

42. Passos, F.; Ferrer, I. Influence of hydrothermal pretreatment on microalgal biomass anaerobic digestion and bioenergy production. Water Res. 2015, 68, 364-373. [CrossRef] [PubMed]

43. González-Fernández, C.; Sialve, B.; Bernet, N.; Steyer, J.P. Comparison of ultrasound and thermal pretreatment of Scenedesmus biomass on methane production. Bioresour. Technol. 2012, 110, 610-616. [CrossRef] [PubMed]

44. Carrere, H.; Antonopoulou, G.; Affes, R.; Passos, F.; Battimelli, A.; Lyberatos, G.; Ferrer, I. Review of feedstock pretreatment strategies for improved anaerobic digestion: From lab-scale research to full-scale application. Bioresour. Technol. 2016, 199, 386-397. [CrossRef] [PubMed]

45. Rodriguez, C.; Alaswad, A.; Mooney, J.; Prescott, T.; Olabi, A.G. Pre-treatment techniques used for anaerobic digestion of algae. Fuel Process. Technol. 2015, 138, 765-779. [CrossRef]

46. Hirano, A.; Ueda, R.; Hirayama, S.; Ogushi, Y. $\mathrm{CO}_{2}$ fixation and ethanol production with microalgal photosynthesis and intracellular anaerobic fermentation. Energy 1997, 22, 137-142. [CrossRef]

47. Martínez, N.; Callejas, N.; Morais, E.G.; Vieira Costa, J.A.; Jachmanián, I.; Vieitez, I. Obtaining biodiesel from microalgae oil using ultrasound-assisted in-situ alkaline transesterification. Fuel 2017, 202, 512-519. [CrossRef]

48. Wang, Y.; Guo, W.; Cheng, C.-L.; Ho, S.-H.; Chang, J.-S.; Ren, N. Enhancing bio-butanol production from biomass of Chlorella vulgaris JSC-6 with sequential alkali pretreatment and acid hydrolysis. Bioresour. Technol. 2016, 200, 557-564. [CrossRef] [PubMed]

49. Efremenko, E.N.; Nikolskaya, A.B.; Lyagin, I.V.; Senko, O.V.; Makhlis, T.A.; Stepanov, N.A.; Maslova, O.V.; Mamedova, F.; Varfolomeev, S.D. Production of biofuels from pretreated microalgae biomass by anaerobic fermentation with immobilized Clostridium acetobutylicum cells. Bioresour. Technol. 2012, 114, 342-348. [CrossRef] [PubMed]

50. Solé-Bundó, M.; Carrère, H.; Garfí, M.; Ferrer, I. Enhancement of microalgae anaerobic digestion by thermo-alkaline pretreatment with lime (CaO). Algal Res. 2017, 24, 199-206. [CrossRef]

51. Mendez, L.; Mahdy, A.; Timmers, R.A.; Ballesteros, M.; González-Fernández, C. Enhancing methane production of Chlorella vulgaris via thermochemical pretreatments. Bioresour. Technol. 2013, 149, 136-141. [CrossRef] [PubMed]

52. Chng, L.M.; Lee, K.T.; Chan, D.J.C. Synergistic effect of pretreatment and fermentation process on carbohydrate-rich Scenedesmus dimorphus for bioethanol production. Energy Convers. Manag. 2017, 141, 410-419. [CrossRef]

53. Khan, M.I.; Lee, M.G.; Shin, J.H.; Kim, J.D. Pretreatment optimization of the biomass of Microcystis aeruginosa for efficient bioethanol production. AMB Express 2017, 7, 19. [CrossRef] [PubMed]

54. Kavitha, S.; Subbulakshmi, P.; Rajesh Banu, J.; Gobi, M.; Tae Yeom, I. Enhancement of biogas production from microalgal biomass through cellulolytic bacterial pretreatment. Bioresour. Technol. 2017, 233, 34-43. [CrossRef] [PubMed]

55. Ciudad, G.; Rubilar, O.; Azócar, L.; Toro, C.; Cea, M.; Torres, Á.; Ribera, A.; Navia, R. Performance of an enzymatic extract in Botrycoccus braunii cell wall disruption. J. Biosci. Bioeng. 2014, 117, 75-80. [CrossRef] [PubMed]

56. Muñoz, C.; Hidalgo, C.; Zapata, M.; Jeison, D.; Riquelme, C.; Rivas, M. Use of cellulolytic marine bacteria for enzymatic pretreatment in microalgal biogas production. Appl. Environ. Microbiol. 2014, 80, 4199-4206. [CrossRef] [PubMed]

57. Passos, F.; Hom-Diaz, A.; Blanquez, P.; Vicent, T.; Ferrer, I. Improving biogas production from microalgae by enzymatic pretreatment. Bioresour. Technol. 2016, 199, 347-351. [CrossRef] [PubMed]

58. He, S.; Fan, X.; Katukuri, N.R.; Yuan, X.; Wang, F.; Guo, R.-B. Enhanced methane production from microalgal biomass by anaerobic bio-pretreatment. Bioresour. Technol. 2016, 204, 145-151. [CrossRef] [PubMed] 
59. Arenas, E.G.; Rodriguez Palacio, M.C.; Juantorena, A.U.; Fernando, S.E.L.; Sebastian, P.J. Microalgae as a potential source for biodiesel production: Techniques, methods, and other challenges. Int. J. Energy Res. 2017, 41, 761-789. [CrossRef]

60. Aydin, S. Enhancement of microbial diversity and methane yield by bacterial bioaugmentation through the anaerobic digestion of Haematococcus pluvialis. Appl. Microbiol. Biotechnol. 2016, 100, 5631-5637. [CrossRef] [PubMed]

61. Velmurugan, R.; Incharoensakdi, A. $\mathrm{MgO}-\mathrm{Fe}_{3} \mathrm{O}_{4}$ linked cellulase enzyme complex improves the hydrolysis of cellulose from Chlorella sp. CYB2. Biochem. Eng. J. 2017, 122, 22-30. [CrossRef]

62. Hernández, D.; Riaño, B.; Coca, M.; García-González, M.C. Saccharification of carbohydrates in microalgal biomass by physical, chemical and enzymatic pre-treatments as a previous step for bioethanol production. Chem. Eng. J. 2015, 262, 939-945. [CrossRef]

63. Guo, H.; Chen, H.; Fan, L.; Linklater, A.; Zheng, B.; Jiang, D.; Qin, W. Enzymes produced by biomass-degrading bacteria can efficiently hydrolyze algal cell walls and facilitate lipid extraction. Renew. Energy 2017, 109, 195-201. [CrossRef]

64. Ward, A.J.; Lewis, D.M.; Green, F.B. Anaerobic digestion of algae biomass: A review. Algal Res. 2014, 5, 204-214. [CrossRef]

65. Cirne, D.G.; Paloumet, X.; Björnsson, L.; Alves, M.M.; Mattiasson, B. Anaerobic digestion of lipid-rich waste-Effects of lipid concentration. Renew. Energy 2007, 32, 965-975. [CrossRef]

66. Palatsi, J.; Laureni, M.; Andrés, M.V.; Flotats, X.; Nielsen, H.B.; Angelidaki, I. Strategies for recovering inhibition caused by long chain fatty acids on anaerobic thermophilic biogas reactors. Bioresour. Technol. 2009, 100, 4588-4596. [CrossRef] [PubMed]

67. Passos, F.; Solé, M.; García, J.; Ferrer, I. Biogas production from microalgae grown in wastewater: Effect of microwave pretreatment. Appl. Energy 2013, 108, 168-175. [CrossRef]

68. Pittman, J.K.; Dean, A.P.; Osundeko, O. The potential of sustainable algal biofuel production using wastewater resources. Bioresour. Technol. 2011, 102, 17-25. [CrossRef] [PubMed]

69. Ehimen, E.A.; Holm-Nielsen, J.-B.; Poulsen, M.; Boelsmand, J.E. Influence of different pre-treatment routes on the anaerobic digestion of a filamentous algae. Renew. Energy 2013, 50, 476-480. [CrossRef]

70. Juneja, A.; Ceballos, R.M.; Murthy, G.S. Effects of environmental factors and nutrient availability on the biochemical composition of algae for biofuels production: A review. Energies 2013, 6, 4607-4638. [CrossRef]

71. Choi, S.P.; Nguyen, M.T.; Sim, S.J. Enzymatic pretreatment of Chlamydomonas reinhardtii biomass for ethanol production. Bioresour. Technol. 2010, 101, 5330-5336. [CrossRef] [PubMed]

72. Gerken, H.G.; Donohoe, B.; Knoshaug, E.P. Enzymatic cell wall degradation of Chlorella vulgaris and other microalgae for biofuels production. Planta 2013, 237, 239-253. [CrossRef] [PubMed]

73. Batstone, D.J.; Keller, J.; Angelidaki, I.; Kalyuzhnyi, S.V.; Pavlostathis, S.G.; Rozzi, A.; Sanders, W.T.M.; Siegrist, H.; Vavilin, V.A. The IWA anaerobic digestion model no 1 (ADM1). Water Sci. Technol. 2002, 45, 65-73. [PubMed]

74. Miao, H.; Lu, M.; Zhao, M.; Huang, Z.; Ren, H.; Yan, Q.; Ruan, W. Enhancement of Taihu blue algae anaerobic digestion efficiency by natural storage. Bioresour. Technol. 2013, 149, 359-366. [CrossRef] [PubMed]

75. Nzila, A. Mini review: Update on bioaugmentation in anaerobic processes for biogas production. Anaerobe 2017, 46, 3-12. [CrossRef] [PubMed]

76. Fermoso, F.G.; Bartacek, J.; Jansen, S.; Lens, P.N.L. Metal supplementation to UASB bioreactors: From cell-metal interactions to full-scale application. Sci. Total Environ. 2009, 407, 3652-3667. [CrossRef] [PubMed]

77. Kim, M.; Gomec, C.Y.; Ahn, Y.; Speece, R.E. Hydrolysis and acidogenesis of particulate organic material in mesophilic and thermophilic anaerobic digestion. Environ. Technol. 2003, 24, 1183-1190. [CrossRef] [PubMed]

78. Chen, Y.; Cheng, J.J.; Creamer, K.S. Inhibition of anaerobic digestion process: A review. Bioresour. Technol. 2008, 99, 4044-4064. [CrossRef] [PubMed]

79. Cabanelas, I.T.D.; Arbib, Z.; Chinalia, F.A.; Souza, C.O.; Perales, J.A.; Almeida, P.F.; Druzian, J.I.; Nascimento, I.A. From waste to energy: Microalgae production in wastewater and glycerol. Appl. Energy 2013, 109, 283-290. [CrossRef]

80. Yenigün, O.; Demirel, B. Ammonia Inhibition in Anaerobic Digestion: A Review. Process Biochem. 2013, 48, 901-911. [CrossRef] 
81. Illman, A.M.; Scragg, A.H.; Shales, S.W. Increase in Chlorella strains calorific values when grown in low nitrogen medium. Enzyme Microb. Technol. 2000, 27, 631-635. [CrossRef]

82. An, M.; Wang, Y.; Liu, F.; Qi, X.; Zheng, Z.; Ye, N.; Sun, C.; Miao, J. Biomass, nutrient uptake and fatty acid composition of Chlamydomonas sp. ICE-L in response to different nitrogen sources. Acta Oceanol. Sin. 2017, 36, 105-110. [CrossRef]

83. Nakakubo, R.; Møller, H.B.; Nielsen, A.M.; Matsuda, J. Ammonia inhibition of methanogenesis and identification of process indicators during anaerobic digestion. Environ. Eng. Sci. 2008, 25, 1487-1496. [CrossRef]

84. Mahdy, A.; Fotidis, I.A.; Mancini, E.; Ballesteros, M.; Gonzalez-Fernandez, C.; Angelidaki, I. Ammonia tolerant inocula provide a good base for anaerobic digestion of microalgae in third generation biogas process. Bioresour. Technol. 2017, 225, 272-278. [CrossRef] [PubMed]

85. Tian, H.; Fotidis, I.A.; Mancini, E.; Treu, L.; Mahdy, A.; Ballesteros, M.; González-Fernández, C.; Angelidaki, I. Acclimation to extremely high ammonia levels in continuous biomethanation process and the associated microbial community dynamics. Bioresour. Technol. 2018, 247, 616-623. [CrossRef] [PubMed]

(C) 2018 by the authors. Licensee MDPI, Basel, Switzerland. This article is an open access article distributed under the terms and conditions of the Creative Commons Attribution (CC BY) license (http://creativecommons.org/licenses/by/4.0/). 